Guest Editorial, part of a Special Feature on Systems Science for Managing Europe's Seas

\title{
Sustaining Europe's seas as coupled social-ecological systems
}

\author{
Laurence Mee, $\underline{\text { Philip Cooper }}^{1}, \underline{\text { Andreas Kannen }}^{2}, \underline{\text { Alison J. Gilbert }}^{3}$ and Tim O'Higgins $^{4}$
}

Key Words: ecosystem approach; Marine Strategy Framework Directive; regional seas; social-ecological systems

\section{BACKGROUND}

There is ample evidence for human alteration of Europe's regional seas, particularly the enclosed or partly enclosed Baltic, Black, Mediterranean, and North Seas. Accounts of habitat and biodiversity loss, pollution, and the decline of fish stocks in these economically, socially, and ecologically important seas demonstrate unsustainable use of the marine environment. At the same time, there is an insufficient quantity and quality of information to enable purely evidence-based management of Europe's seas despite this being a declared goal of many decisionmakers; for example, less than $10 \%$ of the deep sea has been systematically explored (UNEP 2006).

Evidence-based management alone is rarely possible in situations with complex value-laden policy options (Greenhalgh and Russell 2009), and unfortunately, many of the most pervasive problems in the marine environment are "wicked" second-order problems (Jentoft and Chuenpagdee 2009): they are complex in nature and their management will often involve both winners and losers. Solutions to these problems involve less politically attractive, valuebased choices and may require long time lags before tangible results are observed. Fisheries management, habitat and species protection, competition for marine space, and invasive species are all examples of "wicked" problems. These are some of the biggest issues facing Europe's seas and are the major focus of this article and Special Feature.

For the first time in European history, most countries have adopted a common maritime policy (the 2007 Integrated Maritime Policy) and a legally binding environmental directive (the 2008 Marine Strategy Framework Directive [MSFD]). These comprehensive policy vehicles encompass, or closely interface with, more specific measures, such as the recently reformed Common Fisheries Policy, the Water Framework Directive, the Habitats and Birds Directive, and a number of targeted policy instruments that deal with aspects of pollution control and coastal zone management. The overall array of measures has the potential to ensure the sustainable use of Europe's seas and the restoration of marine environments, but the pathway between the current situation and the implementation of an ecosystem approach to management (the aspiration of the European Commission; see Our Approach to Research) is fraught with "wicked" problems.

Science can help society resolve these problems, but in many cases this requires the broad and integrative vision of Odum's (1971) "macroscope" rather than trying to piece together an ill-fitting jigsaw puzzle of discipline-focused information. This paper and the others in this Special Feature employ a systems approach. We describe the approach, how it can be applied practically, and some of the challenges in making it work. Though the work is based on research on Europe's seas, it has much wider implications for regional seas throughout the world.

\section{OUR APPROACH TO RESEARCH ON MARINE SOCIAL- ECOLOGICAL SYSTEMS}

The research described in this paper (and Special Feature) was conducted in the framework of the EU-FP7 funded project Knowledge-based Sustainable Management of Europe's Seas (KnowSeas). The interdisciplinary research spanned 4 years and involved 33 institutions from 16 European countries (KnowSeas 2013). Its primary objective was to develop "a comprehensive scientific knowledge base and practical guidance for the application of the ecosystem approach to the sustainable development of Europe's regional seas." Given the knowledge gaps and uncertainties in the way Europe's marine social-ecological systems function (e.g., unresolved causal links, poorly mapped habitats, nonlinear dynamics), an iterative approach to inquiry was adopted, based partly on the reasoning behind soft systems analysis (e.g., Checkland 2000).

Fig. 1 illustrates the overall approach. Current knowledge of how the "system" (generally defined as one of Europe's regional seas) functions is used to develop a number of simple conceptual models that capture significant components of the system (e.g., key habitats, subsystems, human uses for fishing or renewable

Fig. 1. Approach used for improving understanding of the socialecological system.

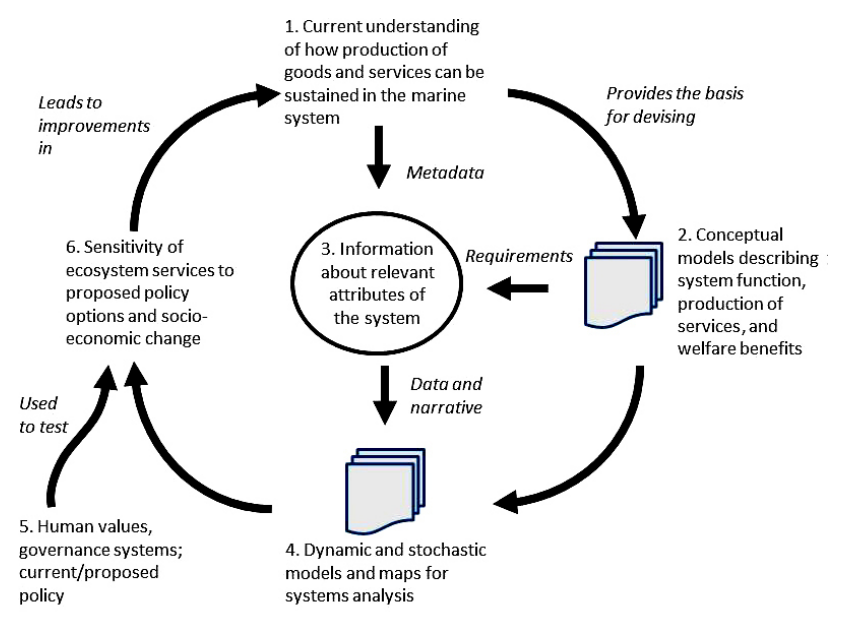

${ }^{1}$ University of Bath, ${ }^{2}$ Helmholtz Zentrum Geesthacht, Centre for Materials and Coastal Research, Department Human Dimensions in Coastal Areas, ${ }^{3}$ Institute for Environmental Studies, VU University Amsterdam, ${ }^{4}$ Scottish Association for Marine Science 
Fig. 2. Structure of the KnowSeas project, using a systems approach for research on coupled social-ecological systems in Europe's seas (WP = Work Package; DG = Directorate General [in the European Commission]; ICES $=$ International Council for the Exploration of the Sea; OSPAR = OSPAR Commission on the NE Atlantic).

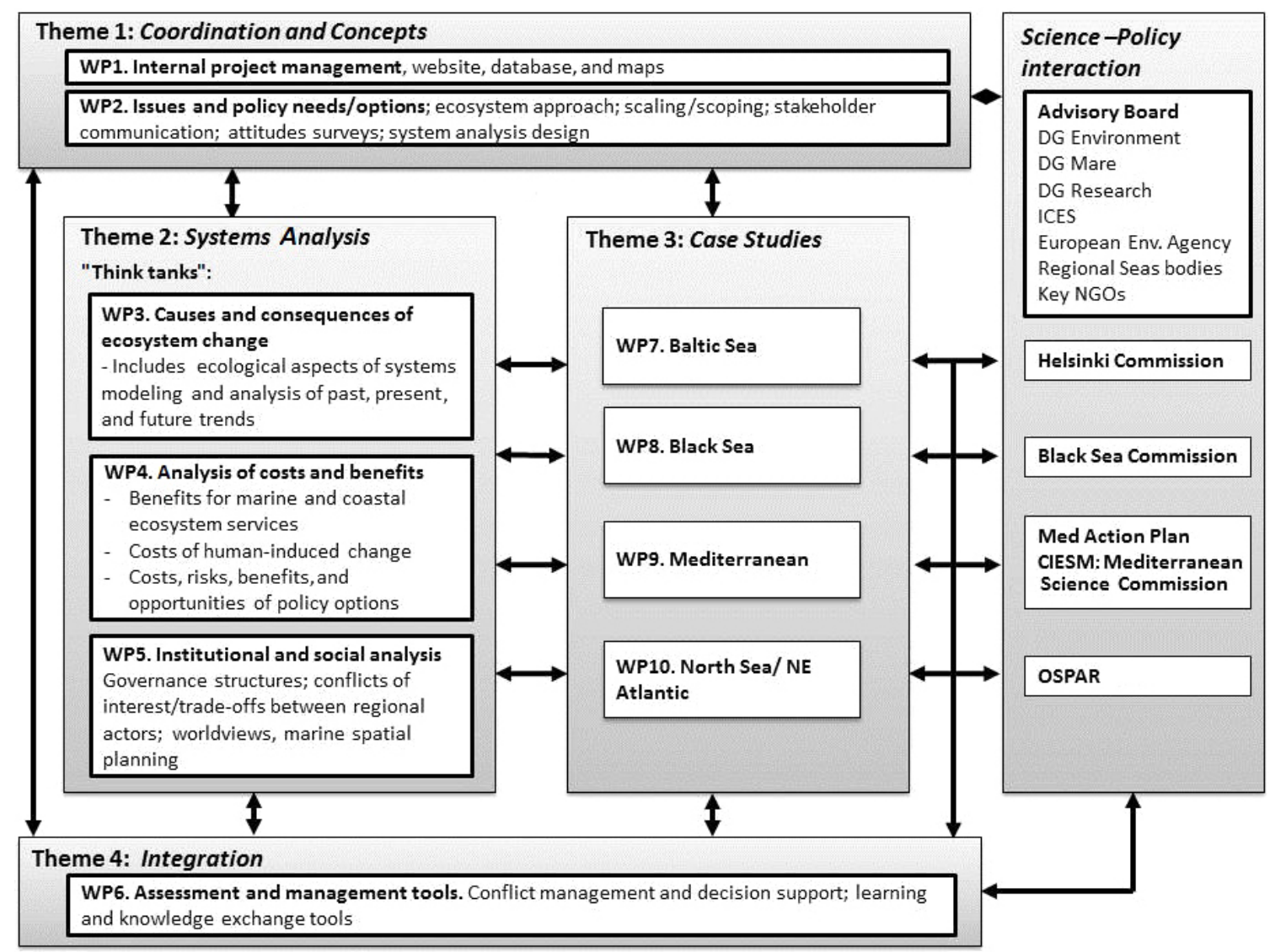

energy). The simple conceptual models help define information needs to build more information-rich systems models that may be quantitative (stochastic or deterministic) or qualitative (narrative-rich logistical models). In parallel, information is gathered on current policies, governance arrangements, and social norms and values (worldviews). These, together with the systems models, enable exploration of the consequences of current or proposed policy for the delivery of ecosystem services and for maintaining the integrity of the system as a whole. All of this enriches understanding of how the system operates, and this new understanding is the departure point for a new iteration of the inquiry process.

This general model for inquiry was adapted according to the realities of each system (the level of current knowledge varies from sea to sea). From a practical perspective, it is challenging to maintain a broad multidisciplinary research effort and to find the necessary complementary skills in every regional sea, particularly in economics and the social sciences. With this constraint, we developed a research strategy for the project (Fig. 2) that enabled a flow of information between those engaged in "big picture" overall thinking and those who were developing regional sea studies. The strategy applied the approach illustrated in Fig. 1 at a number of different scales: (1) a Pan European scale, (2) the European regional seas, and (3) pilot studies of the consequence of economic activities related to specific drivers or, in particular, subregions. Some of the technical expertise was also pooled into three "think tanks" that covered natural, economic, and social aspects of the system. This allowed multidisciplinary teams to be deployed at any scale within the overall system, and facilitated the process of learning - a key element of the systems approach and adaptive management (e.g., Lee 1999).

It was not feasible to conduct detailed studies on every environmental issue in each regional sea, so we developed a matrix of case studies that allowed us to assemble an understanding of a wide range of representative issues that, to varying degrees, are of concern throughout the system. We examined three perspectives of the overall system: (1) its legitimate human uses, as described in the EU Integrated Maritime Policy (fishing, aquaculture, maritime transport, offshore renewables, mineral extraction, carbon capture and storage, closure for conservation and recreation); (2) the major environmental issues in the regional seas within the scope of the EU MSFD (eutrophication, chemical pollution, living resource depletion, and biodiversity/habitat loss); and (3) issues that require solutions that transcend the 
boundaries of the EU (invasive species and climate change). Fig. 3 illustrates how this combination of factors was studied, and it provides a key to the published information arising from the study up to January 2014. Integration of the studies to examine overall system properties is the subject of this paper and the others in this Special Feature.

Fig. 3. KnowSeas regional studies and subregional case studies, showing issue selection criteria (EU MSFD = European Union Marine Strategy Framework Directive).

\begin{tabular}{|c|c|c|c|c|c|c|c|c|c|c|c|c|c|c|}
\hline \multirow[t]{2}{*}{ Study area } & \multicolumn{7}{|c|}{$\begin{array}{l}\text { Legitimate marine system uses } \\
\text { (considered In the EU Integrated } \\
\text { Maritime Policy) }\end{array}$} & \multicolumn{4}{|c|}{\begin{tabular}{|l} 
Environmental \\
issues (within \\
immediate scope \\
of the EU MSFD) \\
\end{tabular}} & \multicolumn{2}{|c|}{\begin{tabular}{|l} 
Larger \\
scale \\
issues
\end{tabular}} & \multirow[t]{2}{*}{ References } \\
\hline & 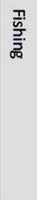 & 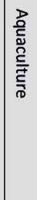 & 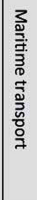 & 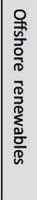 & 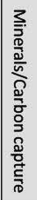 & 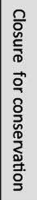 & 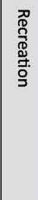 & 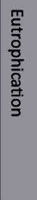 & 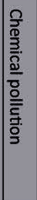 & 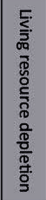 & 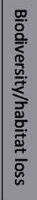 & 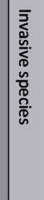 & 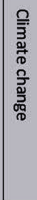 & \\
\hline \multicolumn{15}{|l|}{ WP 7 Baltic Sea } \\
\hline \begin{tabular}{|l|}
$\begin{array}{l}\text { Regional scale } \\
\text { study }\end{array}$ \\
\end{tabular} & - & & - & & & - & & - & $\cdot$ & • & • & - & - & \begin{tabular}{|l|}
$O^{\prime}$ Higgins and Roth 2010 \\
Tomczak et al. 2012, 2013 \\
\end{tabular} \\
\hline $\begin{array}{l}\text { Case study [Gulf } \\
\text { of Finland] }\end{array}$ & & & - & & & - & & - & - & • & $\cdot$ & & & In preparation \\
\hline \multicolumn{15}{|l|}{ WP8 Black Sea } \\
\hline \begin{tabular}{|l}
$\begin{array}{l}\text { Regional scale } \\
\text { study }\end{array}$ \\
\end{tabular} & - & & - & & & - & & - & & - & $\cdot$ & - & & 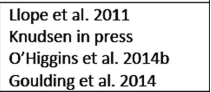 \\
\hline \begin{tabular}{|l|l|} 
Case study 1 \\
[invasive sea snail \\
Rapana]
\end{tabular} & - & & & & & & & - & & - & - & - & - & $\begin{array}{l}\text { Knudsen and Koçak } 2011 \\
\text { Janssen et al. } 2014 \\
\text { Knudsen } 2013 \\
\end{array}$ \\
\hline \multicolumn{15}{|c|}{ WP 9 Mediterranean } \\
\hline \begin{tabular}{|l}
$\begin{array}{l}\text { Regional scale } \\
\text { study }\end{array}$ \\
\end{tabular} & - & - & - & & & - & - & & $\cdot$ & - & - & - & • & \begin{tabular}{|l|} 
Pon and Albaigés 2011 \\
Cinnirella et al. 2012 \\
Barausse and Palmeri 2014 \\
Cinnirella et al. 2013 \\
\end{tabular} \\
\hline $\begin{array}{l}\text { Case study [Gulf } \\
\text { of Lions] }\end{array}$ & & & - & & & & & & - & & & & - & In preparation \\
\hline \begin{tabular}{|l} 
Case Study [N. \\
Adriatic]
\end{tabular} & • & & & & & & & - & & & & & & Barausse et al. 2011 \\
\hline \multicolumn{15}{|l|}{ WP 10 NE Atlantic } \\
\hline \begin{tabular}{|l|} 
Regional scale \\
study
\end{tabular} & - & & - & - & - & . & & & - & - & - & - & - & \begin{tabular}{|l|} 
Heymans et al. 2011 \\
McQuatters-Gollop and \\
Vermaat 2011 \\
Troost et al. 2013 \\
O'Higgins and Gilbert 2014 \\
\end{tabular} \\
\hline $\left.\begin{array}{|l|}\text { Case study 1 } \\
\text { [Protection of } \\
\text { cold water corals] }\end{array}\right]$ & - & & & & & & & & & & • & & - & $\begin{array}{l}\text { Hall-Spencer et al. } 2009 \\
\text { Le Guilloux et al. } 2010 \\
\text { Tittensor et al. } 2010 \\
\text { Söffker et al. } 2011\end{array}$ \\
\hline \begin{tabular}{|l|} 
Case study 2 \\
[wind farm \\
development]
\end{tabular} & & - & & - & & & & & & & & & & $\begin{array}{l}\text { Kannen et al. } 2013 \\
\text { Busch et al. } 2013 \\
\text { Alexander et al. } 2012 \\
\text { Ratter and Kannen } 2013\end{array}$ \\
\hline
\end{tabular}

\section{THE ECOSYSTEM APPROACH: BEACON OR CLICHÉ?}

Much recent policy towards conservation and sustainable use of the marine environment has emphasized that it is underpinned by-or delivers - the "ecosystem approach to management" ([EAM], which we use synonymously with "ecosystem-based management"). We began our KnowSeas project by trying to give greater clarity on what is meant by EAM, defining it as "a resource planning and management approach that integrates the connections between land, air and water and all living things, including people, their activities and institutions" (Farmer et al. 2012). Though there are a number of generally wordy definitions in current use (e.g., by the Convention for Biodiversity, OSPAR and HELCOM, FAO, ICES, COMPASS), we sought a succinct statement that would be understood by policy-makers. What is more difficult for many to understand, however, is that the incorporation of humans in ecosystems requires an understanding of social processes and human preferences just as much as the longer standing study of nonhuman ecology (Waltner-Toews and Kay 2005, Mee et al. 2008). Indeed, the term "ecosystem approach" may deter the engagement of some social scientists and policy-makers who may associate it with the narrower intentions of the conservation movement.

Although the ecosystem approach is intended as a means to reframe planning and management in terms of the long-term efficient and sustainable use of coupled social-ecological systems, the division between social and ecological components is a long standing one. This has led to separate institutions for the use and conservation of marine ecosystems (e.g., fisheries ministries, environment ministries, EU DG Mare, and DG Environment), different epistemologies, and even the meaning given to terms and the language employed to describe them. We highlight this point in the context of the Drivers-Pressures-State-Impact-Response framework, originally developed by the European Environment Agency. We examined interpretations of these terms during a previous project (the EU FP6 project European Lifestyles and Marine Ecosystems [Langmead et al. 2007]) and during KnowSeas. The term "Impact" had been interpreted by some individuals and institutions to mean "impact on nonhuman ecosystems" and others to mean "impact on humans;" each side is firmly entrenched in its own position (see Cooper 2012). We have modified the framework to remove this ambiguity by substituting the term "Welfare" for Impact so that "impact" encompasses both effects on humans and changes in the state of ecosystems, and by showing how the social system is contained within the limits of the natural system (Fig. 3; Cooper 2013). This Driver Pressure State Welfare Response (DPSWR) framework was the basic conceptual model for our further investigations reported here and in this Special Feature. Though it is useful in terms of analysis to distinguish between ecological impacts (State changes) and economic impacts (changes in Welfare), since these delineate disciplinary boundaries, we stress the shared Greek root of these disciplines, "Oikos," meaning household, and recognize that the "household" of economics is nested within, and is entirely dependent on, the wider "household" studied in ecology.

Closely linked to the DPSWR framework is the concept of ecosystem services as elaborated by De Groot et al. (2002) and popularized in the Millennium Ecosystem Assessment (2005). The flow of ecosystem services connects ecosystem function with the benefits accrued to people, and is incorporated in Fig. 4 in the link between "State" and "Welfare." It is important to point out that this flow is not restricted to monetary benefits but also includes psychological and social benefits, and it is the denial (or threat of denial) of these benefits that often triggers a societal response. In a similar manner to the "ecosystem approach," there is some evidence to demonstrate that the term "ecosystem services" may be a difficult term to popularize, as compared with simpler expressions, such as "nature's benefits" (TNC 2010), but it has gained a high degree of acceptance among scientists and policy-makers.

\section{CONCEPTUAL CHALLENGES FOR APPLYING A SYSTEMS APPROACH}

The DPSWR framework masks a high level of complexity and cannot simply be parameterized and converted into a quantitative model. Each "system" (illustrated by the ovals in Fig. 4) is bounded in space and time and may interact with other systems 
or be nested within them. Planetary-scale systems (such as those controlling our climate) are also subjected to human interference, and this will influence ecosystem state, economic and social drivers, and welfare at the lower (local/regional) scale but will require global scale responses. Each of the boxes in Fig. 4 operates at different spatial and temporal scales, and the arrows that connect them often follow complex pathways that may display nonlinear relationships between cause and effect. Additionally, ecosystem state demonstrates natural variability that may be difficult to distinguish from human influence. This inherent complexity poses a considerable challenge to modeling entire coupled social-ecological systems in a deterministic manner; stochastic modeling provides an empirical alternative in some cases. Notwithstanding, systems exhibit "big picture" properties (both inherent and emergent), that can be described and modeled and which have major implications for their management. These include resilience, organization, and vigor (Tett et al. 2013). We have focused on factors that influence resilience, the key system property underpinning sustainability (Folke 2006), as our contribution to the discourse on future marine management. We later explain how these factors can be used as a basis to test the likely effectiveness of new policies to protect and sustainably manage Europe's seas. These factors can be summarized as follows:

Fig. 4. The Driver Pressure State Welfare Response framework developed in KnowSeas, and the basis of further research (based on Cooper 2013).

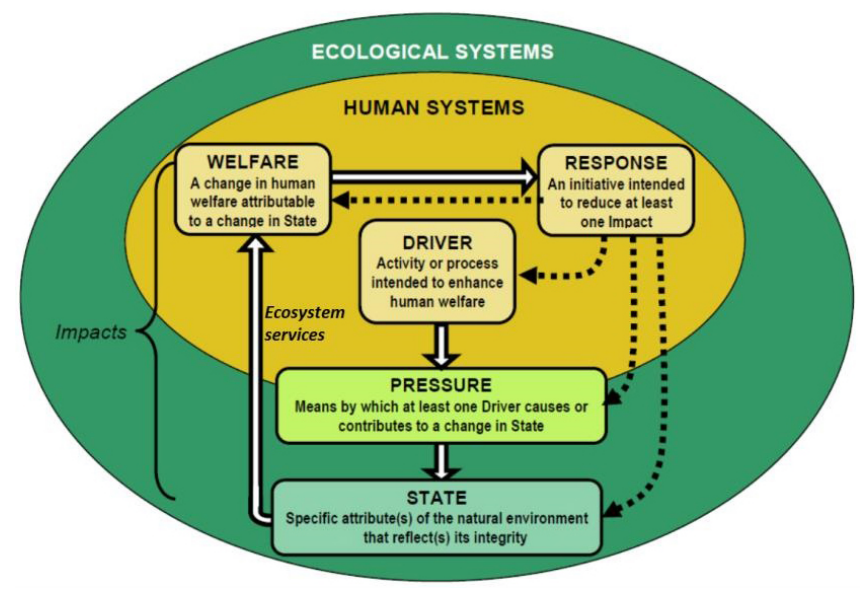

Nonlinearities (and regime shifts)

Much environmental decision-making continues to be predicated on assumptions of smooth (mostly linear) cause-effect relationships. Holling (1973) demonstrated that systems could shift to another resilient state with different functions and controls when a pressure threshold is exceeded. Over subsequent years, increasing evidence of these regime shifts has been found at a number of different scales (Folke et al. 2004). Regime shifts have been reported and studied in tropical and temperate marine ecosystems (e.g., Hughes et al. 2005, Nyström et al. 2012) and in the North Sea (McQuatters-Gollop et al. 2007), the Black Sea (Mee et al. 2005), and the Baltic Sea (Hansson et al. 2011). While humans have contributed to most of these cases, some regime shifts would seem to have been triggered by natural causes, for example, the massive changes that occurred in the North Atlantic in the 1920s and 1930s during a spate of warming (Drinkwater 2006). Blenckner et al. 2015) have considered how to manage systems to take account of nonlinearities, including those in economic and social drivers. A central pillar in this approach is adaptive management.

\section{Nonmatching spatial and temporal scales}

Most natural systems (habitats, populations, or even entire large marine ecosystems) exist within defined spatial and temporal boundaries. Social-ecological systems scales are much more complex, however, partly because the people who use marine systems live on the land, so their activities and institutions operate at different scales than the natural systems they exploit. Socialecological systems can operate at multiple scales: managing Black Sea fisheries requires the six coastal countries to cooperate (Goulding et al. 2014) to achieve tangible results, whereas controlling eutrophication requires the joint efforts of the 14 countries in the Danube and Dnipro basins (O'Higgins et al. $2014 b$ ). Moreover, resolving the problem of invasive species may require global-scale cooperation. The debate on whether to set system boundaries based on natural divisions (e.g., seas, catchments, aquifers) or social systems (countries, political regions, municipalities) has been going on since the early 1970s when UNEP's Regional Seas Programme was defined predominantly by political boundaries, though latterly it has embraced the concept of Large Marine Ecosystems (Mee 2005). In Europe, management of catchments has been regionalized around natural boundaries through the Water Framework Directive (WFD). A scale for marine management has proven more difficult to resolve, although the MSFD is characterized by predominantly natural boundaries and a regional approach that interfaces with the WFD to consider many land-based activities. This has not entirely resolved the conflict of priorities for each geographical scale, however, especially around the practical implementation of marine spatial planning (Gilbert et al. 2015). Additionally, the time it takes to negotiate and implement joint actions tends to increase with the number of countries involved and the multiplicity of institutions and legal and policy changes that become necessary. The lack of rapid visible results from policy measures can lead to stakeholder frustration and even suspension of the measures before they have had time to be effective. The recent signs of improvement in cod stocks in the North Sea, for example, came at a time when the cod recovery plan, already in place for more than 5 years, had been decried by some stakeholders as a failure.

\section{System memory, feedbacks, and locked-in behavior}

Europe's seas suffer from a number of legacy issues where human pressures have already been managed but environmental problems remain, often because of unforeseen feedbacks within the system. The large pool of nutrients in aquifers and marine sediments originating from land-based activities will continue to cycle for many years in enclosed or semi-enclosed seas like the Baltic, Black, or Northern Adriatic, and the expectations of policymakers for system recovery have to be managed accordingly (Artioli et al. 2008). O'Higgins et al. (2014a) characterize different forms of legacy issue in the context of DPSWR with their own implications for management. The human dimension of lockedin behavior has been relatively poorly documented. Gilbert et al. (2015) recently pointed out that human activities in the southern 
North Sea make it virtually impossible to return to a "pristine" state. The current focus on fishing techniques that continuously plough the seafloor locks the ecosystem into its present degraded state, and this is unlikely to change without a huge and expensive shift in social preferences and behavior. Varjopuro et al. (2014) examine how locked-in behavior in both the social and natural systems has made it difficult to deal with eutrophication in a timely manner.

\section{Choke points}

Social-ecological systems are dynamic, but their ability to change and adapt may be constrained by a rate-limiting factor that constitutes a "system choke point." Systems may collapse or fail to recover because of "single point" failure. To illustrate, a huge effort to establish good environmental conditions for restoring natural populations of pandas will be wasted if they are disinclined to procreate. Potts et al. (2015) examine the current and potential choke points for implementation of the MSFD in Europe's regional seas; case studies include psychological choke points in a remote island community, geopolitical choke points at the regional seas level, and critically, economic choke points where the costs of meeting environmental targets outweigh the benefits of achieving them.

\section{ADAPTIVE MANAGEMENT AND THE MARINE STRATEGY FRAMEWORK DIRECTIVE}

Uncertainty is an unavoidable obstacle in the management of marine ecosystems. For decades the strategy of adaptive management has been used as a tool for management where the outcomes of measures cannot be reliably predicted (Holling 1978), and this process of "learning by doing" is incorporated into the MSFD. This is a strength of the Directive and it maintains sufficient flexibility to accommodate the growth in understanding of a particular system as different management strategies are put into place. In this context, programs of measures developed by the member states under the Directive are "essentially hypotheses and management activities [are] tests of these hypotheses" (Waltner-Toews and Kay 2005). The Directive itself provides the slow feedback loop of the adaptive management process (Fig. 5) through the six yearly cycle of target setting and programs of measures.

Fig. 5. The adaptive management framework under the Marine Strategy Framework Directive.

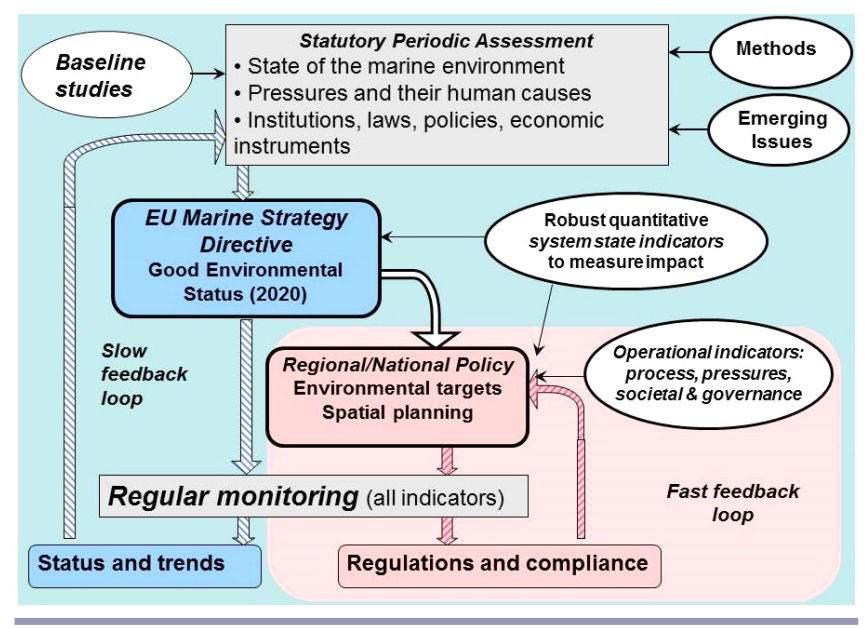

The fast feedback loops of the Directive (Fig. 5) correspond to the actions of individual member states as well as the regional bodies for the management of European regional seas, the level at which the practical management actions take place. The capacity to deal with some of the MSFD descriptors of environmental status already exists (e.g., fisheries, eutrophication) through regional seas institutions such as HELCOM and OSPAR, the Regional Advisory Councils under the Common Fisheries Policy (CFP), and the River Basin District structures established under the WFD. However, developing institutional capacity to manage descriptors related to, for example, energy, noise, and marine litter at the appropriate spatial and temporal scales will be pivotal in determining whether the MSFD can work, not only as an adaptive management tool but also as an instrument towards an ecosystem approach, integrating these critical connections between human activities and ecological phenomena.

In theory, during the current, first assessment cycle of the MSFD, member states are putting in place the processes and practices that should ultimately allow achievement of targets by the 2020 deadline. In practice, due to struggles with economic difficulties, the response to the Directive in some cases has been piecemeal, the member states have been slow to ratify and implement the Directive, and there is insufficient knowledge of certain descriptors to set reliably informed targets. The current adaptive management cycle, to some extent, can be viewed as a "beddingin" period. Beyond 2020, as the MSFD process becomes more familiar to member states, the institutional capacity at the appropriate regional sea, member state, and ecosystem process scales, and the scientific basis for reliable targets will be needed to ensure the MSFD fulfills its potential, to gradually push the State of the marine environment in the desired direction.

\section{VISIONS AND VALUES: A COLLISION COURSE OF VISIONS FOR THE SEA?}

Management of ecosystems is a vision-based process. While the vision of the MSFD is articulated vaguely as "maintaining biodiversity and providing diverse and dynamic oceans and seas which are clean, healthy and productive" (European Commission 2008), the Commission Decision on descriptors (European Commission 2010) refined the practical indicators for Good Environmental Status (GEnS) targets. However, it is left to each member state to set these targets and develop the vision for its own Exclusive Economic Zone (EEZ). Under an EAM, management objectives are considered to be social choices, and management should be decentralized and multisectoral (Mee 2005), demanding both public and private participation in development of a shared vision. While multisectoral representation has emerged in some regional organizations (e.g., the Regional Advisory under the CFP), public participation will require the development of new institutions and effective governance structures to truly incorporate social choice. An even more fundamental obstacle to meaningful public participation has been revealed by our research. Potts et al. (2011) showed that the marine environment is of low priority to the public and that public perceptions of Europe's seas are greatly at odds with the scientific consensus. To achieve an inclusive vision for our seas, as mandated by an ecosystem approach, there is an urgent need to improve public awareness of the benefits the oceans provide and the costs of overexploitation. To realize this improved 
awareness, member states need to develop the "participatory pillar" of the management system described by Sardá et al. (2014).

At present, within Europe there are competing visions for the development of the marine environment. The Integrated Maritime Policy has two clear overarching goals: the economic development from the marine environment through a strategy of "Blue Growth," and safeguarding environmental state through the MSFD under the banner of "Sustainable Development." There is an inescapable tension between these two objectives. Under an ecosystem approach, as envisioned by the MSFD, considerations of social, economic, and ecological capital (people, profits, and puffins) should inform our marine resource decisions. However, as European member states struggle to reestablish economic growth, the limits to growth imposed by ecological systems are less immediate than short-term economic concerns, and exploitation rather than conservation of natural capital may seem economically expedient.

The Blue Growth agenda also provides the context for the most recent European Directive on Marine Spatial Planning (MSP) (European Commission 2014). Member states must now develop spatial plans to set aside marine areas for the purposes of facilitating multiple competing drivers, but if member states are to meet their obligations under the MSFD, these plans will need to consider many aspects of the marine environment, including temporal characteristics, legacy effects (O'Higgins et al. 2014a), and the spatial characteristics of GEnS descriptors. Gilbert et al. (2015) develop a series of principles for MSP to ensure that environmental state is not sacrificed to Blue Growth as spatial plans are developed. The development of these plans has serious consequences for achieving GEnS, as MSP will entail decisions that will effectively lock in the use of marine areas over extended space and time scales.

Within the regional seas, but beyond the boundaries of EEZs under European jurisdiction, there is no shared vision or obligation to achieve GEnS. Economic disparity, political instability, and resulting differences in priorities and values are recurrent themes in the shared regional seas (Cinnirella et al. 2014, O'Higgins et al. 2014b, Varjopuro et al. 2014, Potts et al. 2015). If European governments have difficulty prioritizing GEnS in the relatively affluent nations, then achieving GEnS on the regional sea basis (as mandated by the MSFD), which will require effective cooperation and collaboration with the states of North Africa, the Middle East, and the Russian Federation, is a major, if not insurmountable, obstacle.

\section{REFRAMING MANAGEMENT OPTIONS WITH A DECISION SPACE ANALYSIS: THE NEXT ITERATION}

European directives and local laws regulate what marine managers are obliged to do, just as economic concerns dictate what measures member states are willing and able to take, while unpredictable, and sometimes exogenous, factors determine what is achievable. These social and ecological constraints leave managers with a limited suite of options from which they can choose, and managers need ways of making decisions within this matrix of obligation and uncertainty. Considerations of spatial and temporal scales, both of social systems (of laws and economies) and fluctuating ecological systems, can provide a systematic approach to the identification of management options based on a technique we call "decision space analysis."
Fig. 6 shows a simple matrix of temporal and spatial scales. The spatial scales extend from the land, seaward, sequentially encompassing wider scales of management. The temporal scales are based on politically meaningful periods, extending from a single year to a political term to the timescale of the MSFD and beyond to 2050. Legal obligations generally have explicit timescales and areas of jurisdiction; by contrast, marine environmental problems often cross international boundaries, and their timescales to recovery are often long and unpredictable. Fig. 6 illustrates the spatial and temporal scales associated with major European environmental obligations. The diagram illustrates the increasingly complex policy landscape faced by marine managers, and highlights where the objectives overlap and may come into conflict. For example, the installation of offshore wind farms dictates that the use of space is locked-in over the lifespan of the devices, which in turn limits the capacity of governments to practice adaptive management under the MSFD in these particular locations. This mismatch may result in incompatible policy objectives in certain areas unless there is concerted effort at the institutional level to harmonize the implementation processes of MSP, MSFD, and CFP.

Fig. 6. Decision space analysis matrix of policies relevant to the European marine environment, Water Framework Directive (WFD), Common Agricultural Policy (CAP), and Common Fisheries Policy $(\mathrm{CFP})(\mathrm{EEZ}=$ Exclusive Economic Zone; GEnS = Good Environmental Status; IMP = Integrated Maritime Policy; MSFD = Marine Strategy Framework Directive).

\section{Implementation cycles and policies}

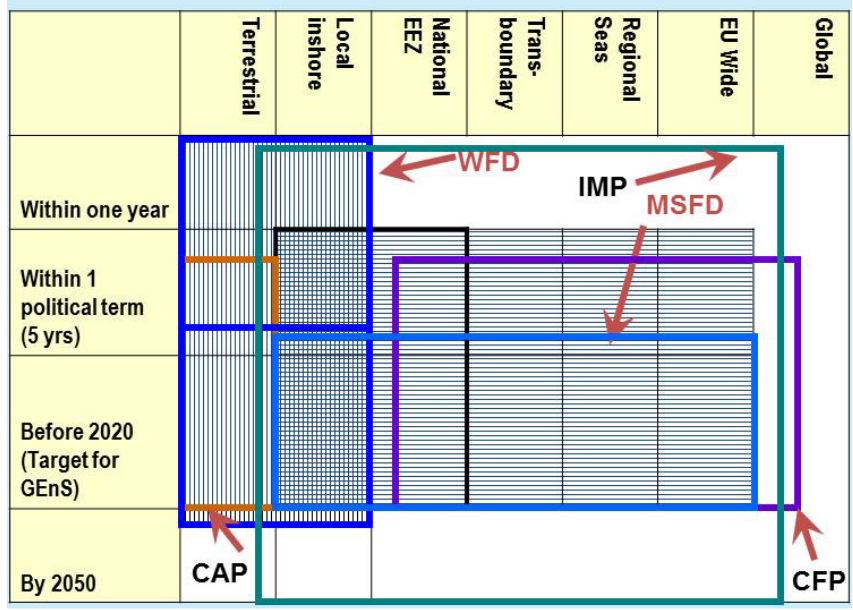

Another example of spatial mismatch comes from the Black Sea (O'Higgins et al. 2014b). Two major environmental problems in the Black Sea are the depleted fisheries (which is a basin-wide phenomenon) and the coastal eutrophication of the North West shelf. Persistent overexploitation and a failure to coordinate environmental management led to a disastrous collapse of the food web, including a failure of the major fisheries and severe and persistent episodes of eutrophication in the late 1980s and early 1990s. The political action to establish a cooperative basis for environmental collaboration between the six, historically inimical, Black Sea nations resulted in the foundation of the Black 
Sea Commission (BSC). The BSC has an ambitious environmental remit: to pursue an ecosystem approach to management (a major legacy of the lead author, the late professor Mee). In this issue, O'Higgins et al. (2014b) under the frame of decision space analysis, identify with hindsight that an analysis of spatial and temporal scales could have provided a more efficient focus on the eutrophication issue. Focusing efforts on the states of the northwestern Black Sea instead of pursuing a regional seas agreement would have obviated the need for protracted negotiation and compromise among the reluctant Black Sea nations for a regional sea-based agreement.

\section{WILL CURRENT POLICY DELIVER AN ECOSYSTEM APPROACH?}

Given the degraded state of Europe's seas, the depletion of fish stocks, and the deterioration of water quality and biodiversity, it is clear that our use of the marine environment has been exceeding our sea's capacity to provide a continued reliable supply of ecosystem services, and has not been sufficiently informed by the ecological limits to exploitation imposed by these systems. The MSFD sets a remarkably ambitious agenda for the marine environment, both in its spatial scale, applying to all of Europe's regional seas, and in the comprehensive ecological scope of the 11 GEnS descriptors, as well as its inclusion of the concept of an ecosystem approach. Achieving GEnS is subject to exogenous forcing, which drives the variability in marine ecosystems, as well as the unpredictable levels of resilience and recovery of the systems themselves, which constrain management actions. In turn, management actions are subject to social forces. The targets for environmental status reflect national priorities, which are shaped by multiple competing objectives. Programs of measures depend on national institutional and economic capacity to implement the Directive. Thus, the properties of both social and ecological systems shape what can be achieved through management action, but the MSFD at least signifies a common commitment to improve ecological outcomes compared to what they would be in the absence of such a transboundary policy.

Achieving the targets of GEnS, through implementation of the MSFD, and attaining an ecosystem approach are not the same thing. Recognition of interconnectivity is the defining feature of the EAM, and its inclusion in the MSFD has far-reaching implications. With social and economic globalization, everything is connected; marine environmental State depends on our activities in the coastal zone and on our institutions and economies, but also on the environmental and economic conditions of our neighbors. If achieving GEnS results in the reduction of particular Driver activities within our regional seas - for example, if we reduce levels of fishing without reducing the demand for fish, we risk simply exporting that Driver along with the consequent environmental degradation, exchanging nonEuropean natural capital for our financial capital, as occurs through our expanding number of third country fisheries agreements. Such solutions represent a "soft" approach to sustainability where natural capital is substitutable for other forms of capital; the concept of "hard sustainability" does not recognize such substitutability (Mee et al. 2008) and would dictate that we curtail our consumption of wild-caught fish where it goes beyond maximum sustainable yield, not just in our own seas but in the global oceans. If we do not wish to simply export our environmental problems, we must, as societies and individuals, examine our own lifestyles and patterns of consumption.

\section{CONCLUSIONS}

Time marches on, political, economic, and environmental conditions change inexorably and unpredictably, and a return to the past is impossible (Gilbert et al. 2014). Our marine systems are embedded in their spatial and temporal contexts, and these present unique and site-specific management challenges. What we can do to manage change is limited, but we must be able to respond to it. The iterative process set out in the MSFD has put in place a structure to facilitate adaptive responses to changing conditions. While the initial cycle of targets and measures may not radically alter the marine environmental state, the structure of the MSFD paves the way for iterative improvement. The analytical tools and concepts refined as part of this research and presented in this Special Feature have the potential to illuminate different social and ecological problems facing us, not just in Europe but around the world. These tools may aid with the gradual journey towards a truly integrated management approach by incorporating the connections between ecological and social systems, aligning the "households" of ecology and economics, and ultimately contributing toward a whole-systems science of "Oikology," but achieving sustainable development of the marine environment will also require changes in lifestyles, behaviors, and values.

\section{Responses to this article can be read online at: http://www.ecologyandsociety.org/issues/responses. $\mathrm{php} / 7143$}

\section{Acknowledgments:}

The research leading to these results has received funding from the European Community's Seventh Framework Programme [FP7/2007-2013] under grant agreement number 226675. The Know Seas project is affiliated with LOICZ and LWEC.

\section{LITERATURE CITED}

Alexander, K. A., R. Janssen, G. Arciniegas, T. G. O’Higgins, T. Eikelboom, and T. A. Wilding. 2012. Interactive marine spatial planning: siting tidal energy arrays around the Mull of Kintyre. PloS One http://dx.plos.org/10.1371/journal.pone.0030031

Artioli, Y., J. Friedrich, A. J. Gilbert, A. McQuatters-Gollop, L. D. Mee, J. E. Vermaat, F. Wulff, C. Humborg, L. Palmeri, and F. Pollehne. 2008. Nutrient budgets for European seas: a measure of the effectiveness of nutrient reduction policies. Marine Pollution Bulletin 56:1609-1617. http://dx.doi.org/10.1016/j. marpolbul.2008.05.027

Barausse, A., A. Michieli, E. Riginella, L. Palmeri, and C. Mazzoldi. 2011. Long-term changes in community composition and life-history traits in a highly exploited basin (northern Adriatic Sea): the role of environment and anthropogenic pressures. Journal of Fish Biology 79:1453-1486. http://dx.doi. org/10.1111/j.1095-8649.2011.03139.x

Barausse, A., and L. Palmeri. 2014. A comparative analysis of trophic structure and functioning in large-scale Mediterranean marine ecosystems. Pages 421-434 in S. Goffredo, H. Baader, and Z. Dubinsky, editors. The Mediterranean Sea: its history and present challenges. Springer, Dordrecht, Netherlands. http://dx. doi.org/10.1007/978-94-007-6704-1_24 
Blenckner, T., A. Kannen, A. Barausse, C. Fischer, J. Heymans, T. Luisetti, V. Todorova, M. Valman, and L. Mee. 2015. Past and future challenges in managing European seas. Ecology and Society, In press. Volume 20 Issue 1.

Busch, M., A. Kannen, S. Garthe, and M. Jessop. 2013. Consequences of a cumulative perspective on marine environmental impacts: offshore wind farming and seabirds at North Sea scale in context of the EU Marine Strategy Framework Directive. Ocean \& Coastal Management 71:213-224. http://dx. doi.org/10.1016/j.ocecoaman.2012.10.016

Checkland, P. 2000. Soft systems methodology: a thirty year retrospective. Systems Research and Behavioural Science 17:S11S58. http://dx.doi.org/10.1002/1099-1743(200011)17:1+<::AIDSRES374>3.3.CO;2-F

Cinnirella, S., M. Graziano, J. Albaigés, J. Pon, C. Murciano, J. Albaigés, and N. Pirrone. 2013. Integrated assessment of chemical pollution in the Mediterranean Sea: Driver-Pressures-StateWelfare analysis. Ocean and Coastal Management 80:36-45. http://dx.doi.org/10.1016/j.ocecoaman.2013.02.022

Cinnirella, S., D. March, T. O’Higgins, C. Murciano, R. Sardà, J. Albaigés, and N. Pirrone. 2012. A multidisciplinary spatial data infrastructure for the Mediterranean to support implementation of the Marine Strategy Framework Directive. International Journal of Spatial Data Infrastructures Research 7:323-351.

Cinnirella, S., R. Sardà, J. Suárez de Vivero, R. Brennan, A. Barausse, J. Icely, T. Luisetti, D. March, C. Murciano, A. Newton, T. O'Higgins, L. Palmeri, M. Palmieri, P. Raux, S. Rees, J. Albaigés, N. Pirrone, and K. Turner. 2014. Steps toward a shared governance response for achieving Good Environmental Status in the Mediterranean Sea. Ecology and Society 19(4): 47. http:// dx.doi.org/10.5751/ES-07065-190447

Cooper, P. 2012. The DPSWR social-ecological accounting framework: notes on its definition and application. Policy Brief No. 3. EU FP7 KNOWSEAS Project.

Cooper, P. 2013. Socio-ecological accounting: DPSWR, a modified DPSIR framework, and its application to marine ecosystems. Ecological Economics 94:106-115. http://dx.doi. org/10.1016/j.ecolecon.2013.07.010

De Groot, R. S., M. A. Wilson, and R. M. J. Boumans. 2002. A typology for the classification, description and valuation of ecosystem functions, goods and services. Ecological Economics 41:393-408. http://dx.doi.org/10.1016/S0921-8009(02)00089-7

Drinkwater, K. F. 2006. The regime shift of the 1920s and 1930s in the North Atlantic. Progress in Oceanography 68(2):134-151. http://dx.doi.org/10.1016/j.pocean.2006.02.011

European Commission. 2008. Directive 2008/56/EC of the European Parliament and of the Council of 17 June 2008 establishing a framework for community action in the field of marine environmental policy. Official Journal of the European Union 25.6.2008 L 164/19.

European Commission. 2010. Commission Decision of 1 September 2010 on criteria and methodological standards on good environmental status of marine waters (notified under document C(2010) 5956)(2010/477/EU)). Official Journal of the European Union L232, 12e24.
European Commission. 2014. Directive 2014/89/EU of the European Parliament and the Council of 23 July 2014 establishing a framework for maritime spatial planning. Official Journal of the European Union L257, 135.

Farmer, A., L. Mee, O. Langmead, P. Cooper, A. Kannen, P. Kershaw, and V. Cherrier. 2012. The ecosystem approach in marine management. EU FP7 KNOWSEAS Project.

Folke, C. 2006. Resilience: the emergence of a perspective for social-ecological systems analyses. Global Environmental Change 16(3):253-267. http://dx.doi.org/10.1016/j.gloenvcha.2006.04.002

Folke, C., S. Carpenter, B. Walker, M. Scheffer, T. Elmqvist, L. Gunderson, and C. S. Holling. 2004. Regime shifts, resilience, and biodiversity in ecosystem management. Annual Review of Ecology, Evolution, and Systematics 35:557-581. http://dx.doi. org/10.1146/annurev.ecolsys.35.021103.105711

Gilbert, A. J., K. Alexander, R. Sardá, R. Brazinskaite, C. Fischer, K. Gee, M. Jessopp, P. Kershaw, H. J. Los, D. March Morla, C. O’Mahony, M. Pihlajamäki, S. Rees, and R. Varjopuro. 2015. Marine spatial planning and good environmental status: a perspective on spatial and temporal dimensions. Ecology and Society, In press. Volume 20, Issue 1.

Gilbert, A. J., A. McQuatters-Gollop, O. Langmead, L. Mee, and J. Vermaat. 2014. Visions for the North Sea: the societal dilemma behind specifying good environmental status. Ambio $\underline{\mathrm{http}: / / \mathrm{dx}}$. doi.org/10.1007/s13280-014-0536-5

Goulding, I., K. Stobberup, and T. O’ Higgins. 2014. Potential economic impacts of achieving good environmental status in Black Sea fisheries. Ecology and Society 19(3):32. http://dx.doi. org/10.5751/ES-06817-190332

Greenhalgh, T., and J. Russell. 2009. Evidence-based policymaking: a critique. Perspectives in Biology and Medicine 52:304-318. http://dx.doi.org/10.1353/pbm.0.0085

Hall-Spencer, J. M., M. Tasker, S. Söffker, S. Christiansen, S. Rogers, M. Campbell, and K. Hoydal. 2009. Design of Marine Protected Areas on high seas and territorial waters of Rockall Bank. Marine Ecology Progress Series 397:305-308. http://dx.doi. org/10.3354/meps08235

Hansson, M., L. Andersson, and P. Axe. 2011. Areal extent and volume of anoxia and hypoxia in the Baltic Sea, 1960-2011. Report Oceanography 42.

Heymans, J. J., S. Mackinson, U. R. Sumaila, A. Dyck, and A. Little. 2011. The impact of subsidies on the ecological sustainability and future profits from North Sea fisheries. PLoS One 6(5):e20239. http://dx.doi.org/10.1371/journal.pone.0020239

Holling, C. S. 1973. Resilience and stability of ecological systems. Annual Review of Ecology and Systematics 4:1-23. http://dx.doi. org/10.1146/annurev.es.04.110173.000245

Holling, C. S. 1978. Adaptive environmental assessment and management. John Wiley and Sons, Chichester, UK.

Hughes, T. P., D. R. Bellwood, C. Folke, R. S. Steneck, and J. Wilson. 2005. New paradigms for supporting the resilience of marine ecosystems. Trends in Ecology \& Evolution 20(7):380-386. http://dx.doi.org/10.1016/j.tree.2005.03.022 
Janssen, R., S. Knudsen, V. Todorova, and A. G. Hoşgör. 2014. Managing Rapana in the Black Sea: stakeholder workshops on both sides. Ocean \& Coastal Management 87:75-87. http://dx.doi. org/10.1016/j.ocecoaman.2013.10.015

Jentoft, S., and R. Chuenpagdee. 2009. Fisheries and coastal governance as a wicked problem. Marine Policy 33:553-560. http://dx.doi.org/10.1016/j.marpol.2008.12.002

Kannen, A., H. Kremer, K. Gee, and M. Lange. 2013 Renewable energy and marine spatial planning: scientific and legal implications. Page 374 in M. H. Nordquiest, J. Nortton Moore, A. Chircrop, and R. Long, editors. The regulation of continental shelf development: rethinking international standards. Brill Online Books and Journals.

KnowSeas. 2013. What is KnowSeas. [online] URL: http://www. knowseas.com/

Knudsen, S., and H. Koçak. 2011. Through boom and bust: coping with poverty in sea snail fisheries on the Turkish Black Sea coast. Pages 221-249 in S. Jentoft and A. Eide, editors. Poverty mosaics, realities and prospects in small scale fisheries. Springer. http://dx.doi.org/10.1007/978-94-007-1582-0_11

Knudsen, S. 2013. Multiple sea snails: the uncertain becoming of an alien species. Anthropological Quarterly 87(1):59-91. http://dx. doi.org/10.1353/anq.2014.0013

Knudsen, S. In press. Marine governance in the Black Sea. In M. Gilek and K. Kern, editors. Governing Europe's marine environment. Ashgate.

Langmead, O., A. McQuatters-Gollop, and L. D. Mee, editors. 2007. European lifestyles and marine ecosystems: exploring challenges for managing Europe's seas. University of Plymouth Marine Institute, Plymouth, UK.

Lee, K. N. 1999. Appraising adaptive management. Ecology and Society 3(2):3. [online] URL: http://www.consecol.org/vol3/iss $2 /$ art3/

Le Guilloux, E., J. M. Hall-Spencer, M. K. Söffker, and K. Olu. 2010. Association between the squat lobster Gastroptychus formosus and cold-water corals in the North Atlantic. Journal of the Marine Biological Association of the United Kingdom 90:13631369. http://dx.doi.org/10.1017/S0025315410000524

Llope, M., G. M. Daskalov, T. A. Rouyer, V. Mihneva, K.-S. Chan, A. N. Grishin, and N. C. Stenseth. 2011. Overfishing of top predators eroded the resilience of the Black Sea system regardless of the climate and anthropogenic conditions. Global Change Biology 17(3):1251-1265. http://dx.doi.org/10.1111/

j.1365-2486.2010.02331.x

McQuatters-Gollop, A., D. E. Raitsos, M. Edwards, Y. Pradhan, L. D. Mee, S. J. Lavender, and M. J. Attrill. 2007. A long-term chlorophyll dataset reveals regime shift in North Sea phytoplankton biomass unconnected to nutrient levels. Limnology and Oceanography 52(2):635-648. http://dx.doi. org/10.4319/10.2007.52.2.0635

McQuatters-Gollop A., and J. E. Vermaat. 2011. Covariance among North Sea ecosystem state indicators during the past 50 years - contrasts between coastal and open waters. Journal of Sea Research 65:284-292. http://dx.doi.org/10.1016/j.seares.2010.12.004
Mee, L. D. 2005. The role of UNEP and UNDP in multilateral environmental agreements. International Environmental Agreements: Politics, Law and Economics 5(3):227-263. http://dx.doi. org/10.1007/s10784-005-3805-8

Mee, L. D., J. Friedrich, and M. T. Gomoiu. 2005. Restoring the Black Sea in times of uncertainty. Oceanography 18(2):100-111. http://dx.doi.org/10.5670/oceanog.2005.45

Mee, L. D., R. L. Jefferson, D. d'A. Laffoley, and M. Elliott. 2008. How good is good? Human values and Europe's proposed Marine Strategy Directive. Marine Pollution Bulletin 56:187-204. http:// dx.doi.org/10.1016/j.marpolbul.2007.09.038

Millennium Ecosystem Assessment. 2005. Ecosystems and human well-being: synthesis [1]. Island Press, Washington, D.C., USA.

Nyström, M, A. V. Norström, T. Blenckner, M. de la Torre-Castro, J. S. Eklöf, C. Folke, H. Österblom, R. S. Steneck, M. Thyresson, and M. Troell. 2012. Confronting feedbacks of degraded marine ecosystems. Ecosystems 15(5):695-710. http://dx.doi.org/10.1007/ s10021-012-9530-6

Odum, H. T. 1971. Environment, power, and society. Wiley, New York, USA.

O’Higgins, T., P. Cooper, E. Roth, A. Newton, A. Farmer, I. C. Goulding, and P. Tett. 2014a. Temporal constraints on ecosystem management: definitions and examples from Europe's regional seas. Ecology and Society 19(4): 46. http://dx.doi.org/10.5751/ ES-06507-190446

O’Higgins, T., A. Farmer, G. Daskalov, S. Knudesn, and L. Mee. 2014b. Achieving good environmental status in the Black Sea: scale mismatches in environmental management. Ecology and Society 19(3):54. http://dx.doi.org/10.5751/ES-06707-190354

O’Higgins T. G., and A. J. Gilbert. 2014. Embedding ecosystem services into the Marine Strategy Framework Directive: illustrated by eutrophication in the North Sea. Estuarine, Coastal and Shelf Science 140:146-152. http://dx.doi.org/10.1016/j. ecss.2013.10.005

O'Higgins, T. G., and E. Roth. 2011. Integrating the CFP and the Marine Strategy for the Baltic. Pages 229-243 in E. Mokness, E. Dahl, and J. G. Støttrup, editors. Global challenges in integrated coastal zone management. Wiley-Blackwell Ltd., Chichester, UK.

Pon, J., and J. Albaigés. 2011. Oil pollution in the Mediterranean. Pages 681-717 in N. Stambler, editor. Life in the Mediterranean Sea: a look at habitat changes. Nova Science Publishers, Inc., New York, USA.

Potts, T., T. O'Higgins, R. Brennan, S. Cinnirella, U. Steiner Brandt, J. De Vivero, J. Beusekom, T. A. Troost, L. Paltriguera and A. Hosgor. 2015. Detecting critical choke points for achieving Good Environmental Status in European Seas. Ecology and Society, In press. Volume 20 Issue 1.

Potts, T., T. O’Higgins, L. Mee, and C. Pita. 2011. Public perceptions of Europe' seas: a policy brief. EU FP7 KnowSeas project.

Ratter, B., and A. Kannen. 2013. Adaptation to change in the North Sea area: marine spatial planning as a new planning 
challenge in times of climate change. Page 596 in B. Glavovic, R. Kay, M. Kelly, and A. Travers, editors. Climate change and the coast_-building resilient communities. Routledge, New York, USA and London, UK.

Sardá,T. O'Higgins, R. Cormier, A. Diedrich, and J. Tintore 2014. A proposed ecosystem-based management system for marine waters: linking the theory of environmental policy to the practice of environmental management. Ecology and Society 19(4):51. http://dx.doi.org/10.5751/ES-07055-190451

Söffker, M., K. A. Sloman, and J. Hall-Spencer. 2011. In situ observations of fish associated with coral reefs off Ireland. Deep Sea Research Part I. Oceanographic Research Papers 58(8):818825. http://dx.doi.org/10.1016/j.dsr.2011.06.002

Tett, P., R. J. Gowen, S. J. Painting, M. Elliott, R. Forster, D. K. Mills, E. Bresnan, E. Capuzzo, T. F. Fernandes, J. Foden, R. J. Geider, L. C. Gilpin, M. Huxham, A. L. McQuatters-Gollop, S. J. Malcolm, S. Suax-Picart, T. Platt, M.-F. Racault, S. Sathyendranath, J. van der Molen, and M. Wilkinson. 2013. Framework for understanding marine ecosystem health. Marine Ecology Progress Series 494:1-27. http://dx.doi.org/10.3354/ $\underline{\text { meps } 10539}$

The Nature Conservancy (TNC). 2010. National voter survey on ecosystem services. The Nature Conservancy, Missoula, Montana, USA.

Tittensor, D. P., A. R. Baco, J. M. Hall-Spencer, J. C. Orr, and A. D. Rogers. 2010. Seamounts as refugia from ocean acidification for cold-water stony corals. Marine Ecology 31:212-225. http:// dx.doi.org/10.1111/j.1439-0485.2010.00393.x
Tomczak, M. T., J. J. Heymans, J. Yletyinen, S. Niiranen, S. A. Otto, and T. Blenckner. 2013. Ecological network indicators of ecosystem status and change in the Baltic Sea. PloS ONE 8. http:// dx.doi.org/10.1371/journal.pone.0075439

Tomczak, M. T., S. Niiranen, O. Hjerne, and T. Blenckner. 2012. Ecosystem flow dynamics in the Baltic Proper-using a multitrophic dataset as a basis for food-web modelling. Ecological Modelling 230:123-147. http://dx.doi.org/10.1016/j. ecolmodel.2011.12.014

Troost, T. A., M. Blaas, and F. J. Los. 2013. The role of atmospheric deposition in the eutrophication of the North Sea: a model analysis. Journal of Marine Systems 125:101-112. http:// dx.doi.org/10.1016/j.jmarsys.2012.10.005

UNEP. 2006. Ecosystems and biodiversity in deep waters and high seas. UNEP Regional Seas Reports and Studies No. 178 UNEP/ IUCN, Switzerland.

Varjopuro, R., E. Andrulewicz, T. Blenckner, T. Dolch, A.-S. Heiskanen, M. Pihlajamäki, U. Steiner Brandt, M. Valman, K. Gee, T. Potts, and I. Psuty. 2014. Coping with persistent environmental problems: systemic delays in reducing eutrophication of the Baltic Sea. Ecology and Society 19(4): 48. http://dx.doi.org/10.5751/ES-06938-190448

Waltner-Toews, D., and J. Kay. 2005. The evolution of an ecosystem approach: the diamond schematic and an adaptive methodology for ecosystem sustainability and health. Ecology and Society 10(1):38. [online] URL: http://www.ecologyandsociety. org/vol10/iss1/art38/ 